\title{
Study of Morphology and Agar Contents in Some Important Gracilaria Species of Indian Coasts
}

\author{
Nivedita Sahu ${ }^{1,2}$, Dinabandhu Sahoo ${ }^{1}$ \\ ${ }^{1}$ Department of Botany, University of Delhi, Delhi, India; ${ }^{2}$ CSIR-Indian Institute of Chemical Technology, Hyderabad, Andhra \\ Pradesh, India. \\ Email: nivedita@iict.res.in,dbsahoo@hotmail.com
}

Received November $18^{\text {th }}, 2013$; revised December $3^{\text {rd }}, 2013$; accepted December $18^{\text {th }}, 2013$

Copyright (C) 2013 Nivedita Sahu, Dinabandhu Sahoo. This is an open access article distributed under the Creative Commons Attribution License, which permits unrestricted use, distribution, and reproduction in any medium, provided the original work is properly cited.

\begin{abstract}
This study reports the morphological, anatomical and agar content difference among various species of Gracilaria. The cortex was found 1 - 2 layered in G. edulis and G. eucheumatoides whereas 5 - 6 layered in G. foliifera and G. crassa. The medulla was 6 - 8 layered in G. edulis, 10 - 11 layered in G. foliifera, 14 - 15 layered in G. eucheumatoides and 8 10 layered in G. crassa. Similarly, distinct variations were observed in the structure of cystocarp of these taxa. The outer pericarp was 6 - 8 layered in G. verrucosa (attached type), 8 - 9 in Graciriopsis megaspora, 12 - 13 layered cells in G. edulis, 9 - 11 layered in G. foliifera, 12 - 15 layered in G. eucheumatoides and 11 - 14 layered in G. crassa. The tubular nutritive filaments were radiating type in $G$. edulis whereas these were penetrating and radiating type in $G$. foliifera. In G. crassa, the same was produced from a small swollen short base and in G. verrucosa (attached type) it was long. Further, in G. eucheumatoides and Gracilariopsis megaspore, nutritive filaments were not observed. Among various species of Gracilariales studied in this work, agar from Gracilaria verrucosa (floating type or sterile type) showed highest yield with gel strength $260 \mathrm{gm} / \mathrm{cm}^{2}$ and viscosity 10 milipass. Based on the agar quality, in-vitro culture study was done on $G$. verrucosa. This study confirms Gracilariales as important indigenous seaweed which can be taken for large scale cultivation tool.
\end{abstract}

Keywords: Gracilaria verrucosa; Gracilariopsis megaspora; Morphology; Anatomy; Agar Quality

\section{Introduction}

Agar is a complex polysaccharide, mainly extracted from some red seaweeds like Gracilaria spp., Gracilariopsis spp., Gelidium spp., Gelidiella spp., Pterocladia spp. etc. Out of these few genera, Gracilaria and Gracilariopsis known as Gracilarioids contribute to nearly $53 \%$ of the world's total agar production $[1,2]$.

Gracilaria species are utilized as human food, mostly in salads and soups [3-5] as feed, for many animals such as abalone [6] as potential candidates, for nutrient removal for wastewater treatment [7] and as biomass, for energy generation [8-10]. Gracilaria has also been used as food for shellfish (abalone) [11]. Based on this demand of the seaweed, a study on the cultivation of Gracilaria edulis has been made recently [12].

Worldwide Gracilaria Greville is the third largest genus in Rhodophyceae and includes more than 180 species whereas Gracilariopsis has only 7 species. Out of these, about 28 species of Gracilaria and 2 species of Gracila- riopsis have been reported from different parts of the Indian coast [13-15]. Although a number of studies have been carried out on these Gracilarioids, unfortunately the taxonomic position of both Gracilaria and Gracilariopisis still remains chaotic. Besides this, information on Indian Gracilaroids, especially the species growing in Chilika lake, is merged [16].

This paper focuses on the structure, development and agar contents of these two taxa and provides several interesting information. In this study, species of Gracilaria were distinguished by using the following criteria-habits: nature of gradation between cortex and medulla, nature of cells in the center of gonimoblast, nature of spermatangial cavity, base and shape of the cystocarp, absorbing filaments and the structure of pericarp.

\section{Materials and Methods}

Plants of Gracilaria verrucosa (Hudson) Papenfuss and Gracilariopsis megaspora Dawson were collected from 
different sites of Chilika lake, Orissa $\left(19^{\circ} 28^{\prime}-19^{\circ} 54^{\prime} \mathrm{N}\right.$ and $85^{\circ} 05^{\prime}-85^{\circ} 38^{\prime}$ E). Gracilaria eucheumatoides Harvey was collected from ChidiyaTapu, the southern Andaman Island $\left(06^{\circ}-14^{\prime} \mathrm{N}\right.$ and $\left.92^{\circ}-94^{\prime} \mathrm{E}\right)$ which is about $25 \mathrm{~km}$ from Port Blair. Gracilaria edulis (S. Gmelin) P. Silva, G. foliifera (Forsskal) Børgesen, G. crassa Harvey ex J. Agardh, G. corticata (J. Agardh) J. Agardh were collected from different parts Mandapam coast, TamilNadu $\left(09^{\circ} 06^{\prime}-09^{\circ} 14^{\prime} \mathrm{N}\right.$ and $\left.78^{\circ} 53^{\prime}-79^{\circ} 24^{\prime} \mathrm{E}\right)$.

The present study has been made with an objective to solve the complexity of the structure and reproductive biology of the above species. Selected parts from the vegetative and reproductive thalli were dissected and fixed in various fixatives viz. 4\% Formalin made in seawater, FAA and $10 \%$ Acrolein for LM studies. To study the agar quality, collected samples of Gracilaria spp., $G$. verrucosa (Hudson) Papenfuss (M-I and M-II), G. edulis (S. Gmelin) P. Silva, G. foliifera (Forsskal) Børgesen, G. crassa Harvey ex J. Agardh, and G. corticata (J. Agardh) J. Agardh, were shade dried, packed in the gunny bags, and transported to laboratory. The dried seaweed samples containing 7\% - 10\% moisture were stored in plastic bags. Before extraction of agar, the seaweeds were washed thoroughly with tap water to remove the epiphytes and extraneous impurities. All the sample specimens were submitted to the Marine Algal Biotechnology Laboratory, Department of Botany, University of Delhi, herbarium after identification.

Extraction of agar was done by following the protocols of $[17,18]$ with a little modification. $20 \mathrm{~g}$ each were soaked in $400 \mathrm{~mL}$ water for $1 \mathrm{~h}$ at room temperature followed by $2 \mathrm{~h}$ at $90^{\circ} \mathrm{C}$ in a water bath. The soaked seaweed was cooked in an autoclave with distilled water for $1.5 \mathrm{~h}$ at $120^{\circ} \mathrm{C}$. The cooked seaweed (both non-alkali and alkali) was then homogenized in a grinder mixture, boiled with Celite and charcoal and filtered through a Celite bed under vacuum to obtain the clear extract. The filtrate was held at room temperature for gel formation, and the gelled material was then frozen in the freezer at $4{ }^{\circ} \mathrm{C}$ for $15 \mathrm{~h}$ and thawed to obtain the native agar. Finally the thawed agar was air-dried for $24 \mathrm{~h}$ at ambient conditions and then sun dried.

\section{Results}

\subsection{Anatomy of Thallus and Cystocarp}

At Chilika Lake, two different morphotypes of Gracilaria verrucosa are found growing in two distinct habitats. The "attached type" or M-I are reddish brown in color, erect, found to be morphologically different from the plants of $G$. verrucosa "floating type" or M-II. The plants of M-I are reddish brown, purple or yellowish in colour, erect, throughout terete and grow up to $65 \mathrm{~cm}$ (Figure 1(a)), sub-dichotomous and sometimes branches of all orders are found to beset with small proliferations. These plants are either fertile type or sterile type. The fertile plants are found growing on rocky substratum, attached by a small discoid holdfast (Figure 1(a)). The vegetative, male gametophyte and female gametophyte are not distinguishable to naked eyes. The cystocarpic plants can be easily identified because of prominent cystocarps (Figure 1(b)) whereas the tetrasporic plants give a rough touch to hand. In contrast, plants of M-II are found growing loosely in the muddy substratum. These are deep brown in colour, comparatively smaller than the attached type and grow up to $20 \mathrm{~cm}$ (Figure 1(c)). Branching is up to $3^{\text {rd }}$ to $4^{\text {th }}$ order, sub-dichotomous with attenuated tips. These plants are found sterile.

In the present study the Gracilariopsis megaspora was found growing upto $50 \mathrm{~cm}$ long on rocky substratum. Fredericq and Hommersand [19] reported plants of $G$. lemaneiformis growing upto $40 \mathrm{~cm}$ in length. Similarly, Rao [20] found G. megaspora growing upto $18-25 \mathrm{~cm}$. Thus, we conclude that like Gracilaria verrucosa, plants of Gracilariopsis megaspora show a wide range of variabilities. In field, the male and tetrasporic plants are identical to each other whereas the female plants can be distinguished easily due to the presence of larger number of cystocarp. The cystocarps are larger in size, protruded and scattered over the surface of the thallus (Figure 2). The plants are reddish purple or yellowish in colour. The thallus is terete, round, branches up to 3 to 4 order (Figure 2). Branching is irregular with tapering apices. The plants are dioceous and can be distinguished in the field.
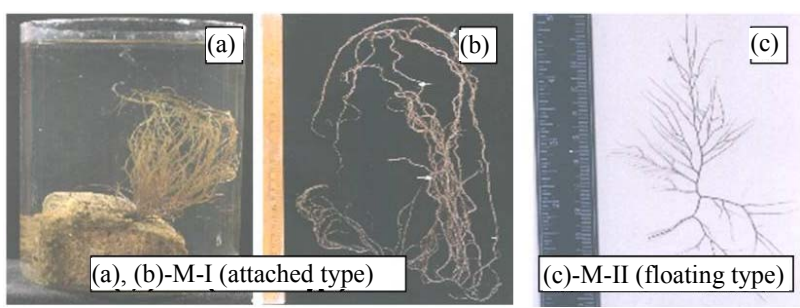

Figure 1. (a)-(c) Two morphotypes of Gracilaria verrucosa from Chilika Lake.

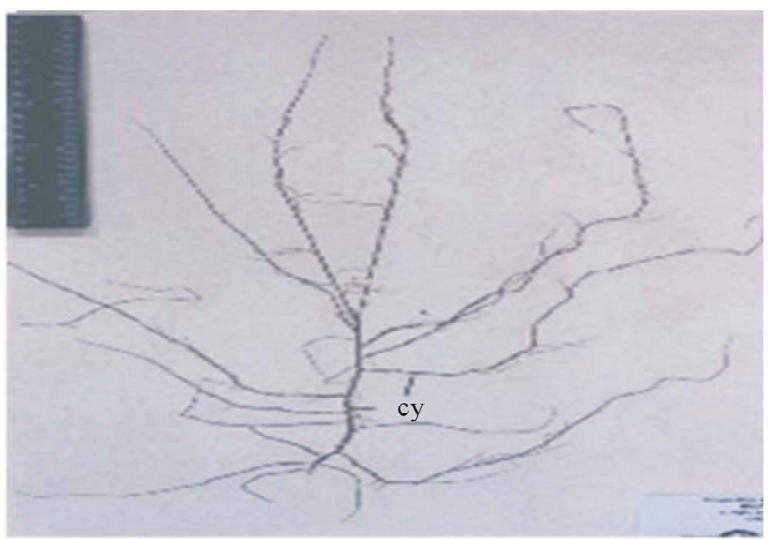

Figure 2. Gracilariopsis megaspora from Chilika Lake. 
Plants collected from Mandapam vicinity and Andaman Islands i.e. Gracilaria edulis, G. foliifera, G. crassa, G. corticata and G. eucheumatoides were found growing in the intertidal zones of this coast. These plants showed high degree of morphological variabilities and can be easily identified by their colour, size and texture of the thallus (Figures 3(a)-(e)). The plants of G. edulis are solitary, erect, cylindrical and grows upto 20 to $25 \mathrm{~cm}$. Usually arising from a small discoid holdfast. The plants are usually attached to the corals, small stones or pebbles and reddish brown in colour (Figure 3(a)). The thalli are highly branched upto 3 to 4 order. Branching is lateral, sometimes sub-dichotomous, opposite or subopposite, often alternate and highly polymorphic. Ultimate branches are short, about $1.5-5 \mathrm{~cm}$ long with curved like tendrils. Branches are found thin at the base becoming thicker in the middle and further attenuating towards the base. Cystocarpic thalli are longer than the tetrasporic and gametophytic thalli. Cystocarps are elevated, urn-shaped and scattered over the surface (Figure 3(a)).

Gracilaria foliifera are flat, translucent, dull purple or reddish brown in colour and measures up to $10-15 \mathrm{~cm}$. These plants are dichotomously or polydichotomously branched with alternate branched fronds thus giving rise a bushy appearance (Figure 3(b)). Fronds are membranous, brittle with compressed stipe about $0-2 \mathrm{~cm}$ wide near base, frequently with laciniate ends. Stipe expand

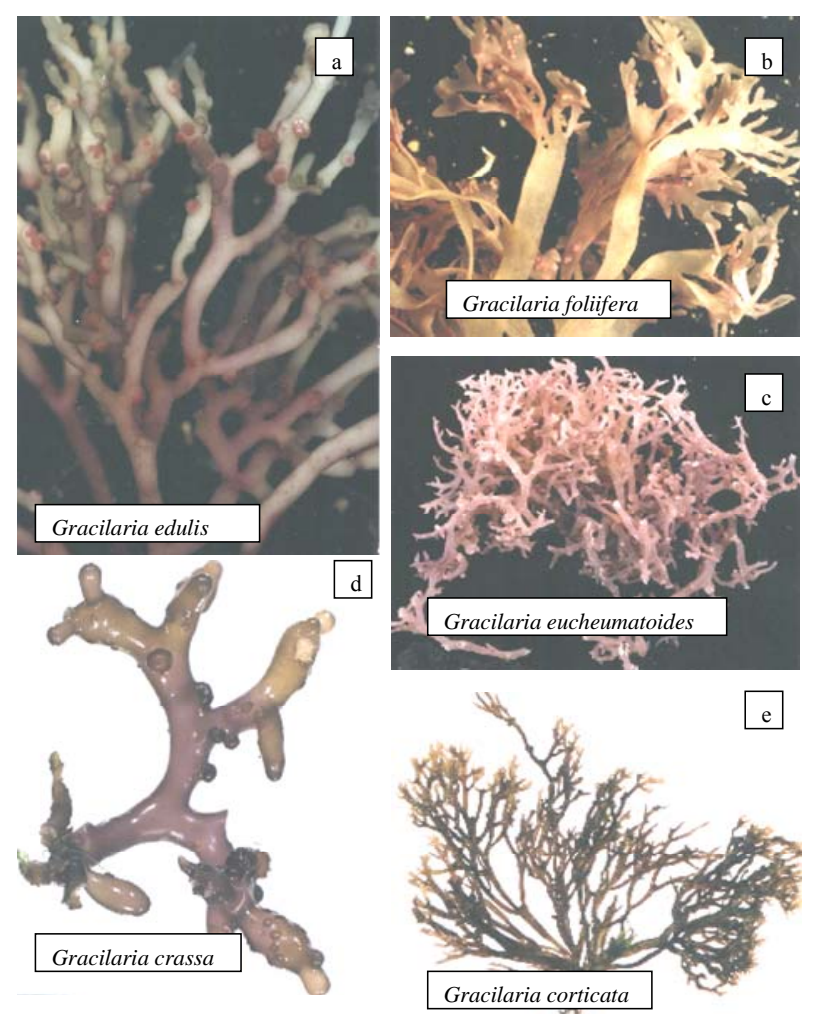

Figure 3. (a)-(e) Gracilaria species from different coast of India. gradually into a blade which is upto $1 \mathrm{~mm}$ thick and upto $1 \mathrm{~cm}$ broad between dichotomous. The margin of the blade is frequently proliferous. Cystocarps are elevated, subspherical, constricted at the base about $0.1-0.2 \mathrm{~cm}$ wide, scattered over the thallus (Figure 3(b)).

Thallus of G. eucheumatoides is dark red to purplish red in colour, upto $5-8 \mathrm{~cm}$ in length, conspicuous and attached by haptera. The thalli are fleshy, compressed and irregularly dichotomously branched (Figure 3(c)). The cystocarps are protruded and scattered all over the thallus.

Plants of G. crassa are short, thick, cylindrical, about 5 $\mathrm{cm}$ in height, $0.2 \mathrm{~cm}$ in thickness and greenish in colour. It has an irregular to discoid holdfast which forms a dense cushion like structure on its substratum. Branching is dichotomous and the branches bend towards the substratum (Figure 3(d)). Thallus is fleshy and segmented near apices. The cystocarpic thallus can be easily distinguished due to the presence of dome shaped cystocarps (Figure 3(d)). The cystocarps are about $0.2 \mathrm{~cm}$ wide and sparsely scattered over the thallus (Figure 3(d)). Male plants are identical to the tetrasporic plants and it is difficult to identify through naked eyes. Male plants are slightly thicker and shorter than the other thalli.

Plants of G. corticata are reddish brown to pink in colour and about $10-12 \mathrm{~cm}$ in height. Fronds are cartilaginous and show repeated dichotomous branching. Thallus is usually $1-2 \mathrm{~cm}$ wide, flat with acute segmented tips (Figure 3(e)). Cystocarpic plants can be easily identified in the field. Tetrasporophytic plants give slight rough touch to finger.

\subsection{Analysis of Agar}

Gracilaria from Indian coast have been known to contain low-grade agar. Amongst those Gracialria verrucosa from Chilika Lake has been reported to be the most potential source of agar in terms of yield. To improve the agar quality we need to develop improved methods of agar extraction processes and better strain of G. verrucosa through the tissue culture techniques. Cote and Hanisak [21] have reported high gel strength of $140 \pm 21$ $\mathrm{g} / \mathrm{cm}^{2}$ and agar yield of $25 \% ; 26 \%$ in G-7 and G-16 respectively, two strains of $G$. verrucosa. In the present study, a distinct variation in the yield, gel strength and gel viscosity was found between the agar extracted with alkali $(5 \% \mathrm{NaOH})$ as well as without alkali. Figures 4(a)-(c) shows the variation in agar quality of Gracilaria verrucosa (M-I, M-II), G. edulis, G. foliifera, G. crassa and G. corticata. The agar content in M-II shows a maximum yield and high gel strength in alkali treated method (Figures 4(a) and (b)).

\section{Discussion}

Ohmi [22] reported free-living Gracilaria in shallow tur- 


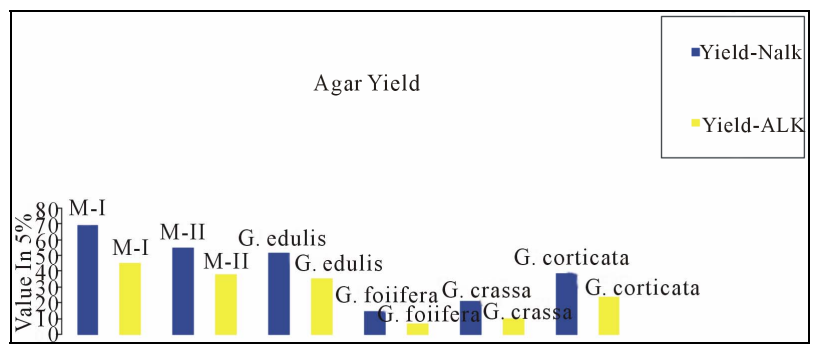

(a)

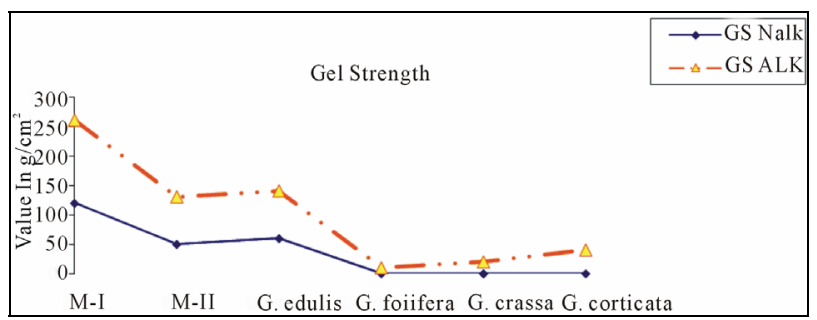

(b)

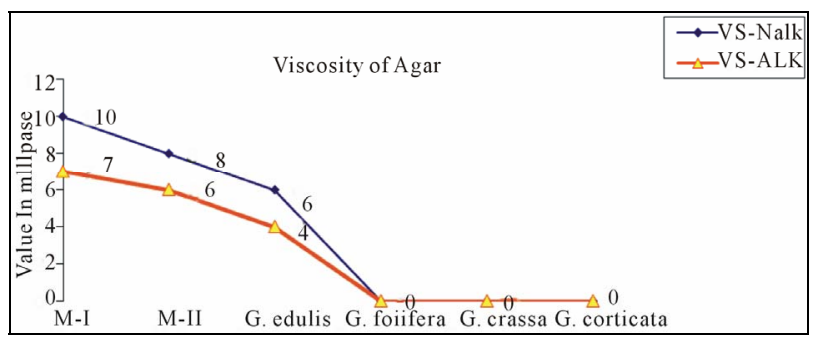

(c)

Figure 4. ((a)-(c)): Comparison of agar quality between nonalkali (Nalk) and alkali method (Alk).

bid waters where the salinity was very low. Critchley [23] reported that attached populations of Gracilaria frequently contain fertile individuals and the free-living populations which are entirely sterile, reproducing only by vegetative means (fragmentation). Thus, the present finding on two different morphotypes of $G$. verrucosa supports the reports of Ohmi and Critchley. Another gracilarioids, Gracilariopsis megaspora was found growing in mixed population with M-I in Kalijai Island and Pathara, Chilika Lake [13]. Rao [20] reported Gracilariopsis megaspora growing in Balugaon, Chilika Lake. However, in present case no such plants were found from Balugaon habitat which favors the growth of M-II "the floating type". Steentoft et al. [24] also reported the occurrence of G. longissima along with Gracilaria gracilis (as G. verrucosa) collected from Britain.

\subsection{Anatomy of Thallus and Cystocarp}

Gracilaria [25] and Gracilariopsis [26] are two stingy gracilarioids, which include many species with taxonomic complexities. This is primarily due to the high degree of morphological variations and incomplete knowledge of their reproductive features. Anatomically, the thal- lus in Gracilaria is differentiated into outer cortex and inner medulla. The number and size of the cells varies in both the morphotypes of G. verrucosa and Gracilaria species. The thallus is pseudoparenchymatous and shows a progressive increase of cell size from cortex to medulla. Withell et al. [27] found that in Gracilaria, the type of transition in cell size from cortex to medulla (whether abrupt or gradual) to be consistent within species. However, in the present study number and size of the cells varies in both the morphotypes of $G$. verrucosa. The cortex is 2 - 3 layered in M-I whereas it is made up of single layered cells in the M-II. The outer layer of cortical cells are radially elongated and highly pigmented in the M-I whereas these cells are comparatively smaller, roundishoval, compact and pigmented in M-II. The medullary cells of floating type are larger in size than the former. This suggests that the large size of medullary cells in M-II could be the region responsible for the plant to remain in free-floating condition. The thalli in Gracilariopsis megaspora are differentiated into outer cortex and the inner medullary. The cortex is 2 - 3 layered, composed of thick walled and compact cells. The cortex is $1-2$ layered in $G$. edulis and $G$. eucheumatoides where as the same is 5 - 6 layered in G. foliifera and G. crassa. The medulla is 6 - 8 layered in G. edulis, 10 - 11 layered in $G$. foliifera, 14 - 15 layered in G. eucheumatoides and 8 - 10 layered in G. crassa. The details of developmental studies of G. verrucosa (M-I and M-II) and Gracilariopsis megaspora have been well reported [14].

The cells of outer layer of the cortex are highly pigmented as compared to the inner layer of cortex and the medulla. The medullary cells are ovoid and large in size. In the present study, the thallus reveals progressive increase in size from the small-celled cortex to large celled medulla except $G$. foliifera. Steentoft et al. [24] reported the differentiation of the medulla and cortex in Gracilariopsis was due to abrupt changes whereas in Gracilaria gracilis (as G. verrucosa) was due to gradual changes.

Based on histochemical stainings, it was observed that the cortical cells possess abundant amount of polysaccharides. The peripheral cortical-cells overarched by a thick extracellular layer, and these extracellular layer veneers the cortical layer with a mixture of polysaccharides since it stains positively with TBO and PAS reagent.

Desikachary et al. [28] reported the abrupt size in the cells of medulla in G. foliifera. Bird and Oliveira [29] reported smaller size of medullary cells in G. megaspora ( $\leq 100$ micrometer).

The cytoplasm of medulla stains positive with TBO indicating the presence of both sulphated and carboxylated polysaccharides in this region. The intercellular space stains positively with TBO and PAS suggesting that it contains sulphated, carboxylated and insoluble polysac- 
charides. These spaces stain comparatively high with TBO than PAS and replete with CBB. Since G. verrucosa is an agarophyte, this suggests that polysaccharides present in the extracellular layer, cell wall and cytoplasm of cortical and medullary cells are agar whereas the polysaccharides present in the intercellular spaces of the cortical region and medullary region provide strength as well as flexibility to the thallus. Since the cell wall stain with both TBO and PAS, its polysaccharides give rigidity to the thallus, the present histochemical study proves this. Talarico et al. [30] reported the intercellular matrix in $G$. verrucosa contains granules and microfibrils; $\mathrm{Ku}-$ mar [31] further supported this study in G. corticata. Kloareg and Quatrano [32] concluded that the fibrillar component together with matrix polysaccharides are involved in regulating mechanical and osmotic factors related to environmental stress.

In the present study morphology and anatomy of cystocarp shows wide range of variation from species to species. The cystocarp of the above taxa showed distinct variation in their structures. The outer pericarp is $12-13$ layered cells in G. edulis, 9 - 11 layered in G. foliifera, 12 - 15 layered in G. eucheumatoides and 11 - 14 layered in $G$. crassa. The tubular nutritive filaments are radiating type in G. edulis where as these are penetrating and radiating type in G. foliifera. In G. crassa these filaments are produced from a small swollen base and are short. Further, in G. eucheumatoides, nutritive filaments were not observed. A unique feature of Gracilaria, the occurrence of nutritive tubular filaments given by Sjoestedt [33] was further renamed as "gonimonemata" by Krishnamurthy and Rajendran [34].

Both radiating and basal type of gonimonimata was observed in G. crassa, G. edulis and G. corticata [35]. In G. foliifera, the gonimoblast are found encircling the gonimoblast at the base of the cystocarp. In the present study, the nutritive filaments are found radiating type in G. edulis and G. foliifera. In G. verrucosa both types of filaments are present. The cells of these filaments are rich in sulphated and carboxylated polysaccharides as these stains positively with TBO. Yamamoto [36] found the tip of the tubular nutritive filaments to have pit-connections with cells of the pericarp. However, the absence of such pit-connection in the Indian species of Gracilaria has been reported $[34,36,37]$. This observation supports the present work. The nature and structure of the pericarp is getting another criterion for the classification of Gracilaria [38]. In G. verrucosa the outer region of pericarp consists of radially elongated cells, which are and arranged in rows. The cells of inner region are star shaped and attached to each other by prominent pit-connections. These pit-connections are distinct and proteinaceous in nature as these stains deep with CBB. The number of cells varies from one species of another, which affects the thickness of the pericarp. Differences in pericarp structure have been use to distinguish species $[39,40]$. The inner pericarp is absent in G. verrucosa but present in Gracilariopsis megaspora and other species of Gracilaria studied in the present study. Walls of ring cells in the base of the Gracilaria gracilis (as G. verrucosa) cystocarp reacted in the same way with TBO or methylene blue as the vegetative cell wall, inner pericarp in Gracilariopsis longissimma did not react [24].

The shape of gonimoblast region varies distinctly in different species of Gracilaria supports the observation of Desikachary et al. [28] who also reported similar lobes of gonimoblast cells in G. edulis.

In the cystocarp of $G$. foliifera, a large cavity is filled with mucilage (present work). The mucilage stains deep magenta with PAS indicating the presence of high amount of insoluble polysaccharides. Steentoft et al. [24] observed the positive stain of TBO in the gonimoblast of Gracilaria gracilis (G. verrucosa), indicating the presence of sulphated polysaccharides, which is also found in the present work. The mode of formation of carposporangia in Gracilaria needs a critical examination. It is assumed that carposporangia in Gracilaria are formed in chains. However, the present study showed that in several species, these were formed in two alternating series from an end cell of the gonimoblast, suggesting a sympodial development of the chain of carposporangia, as observed by Krishnamurthy and Rajendran [34]. The inner gonimoblast cell in G. verrucosa and Gracilariopsis megaspora is responsible for the formation of carp sporangia. Similar type of development of carposporangia in G. verrucosa and Gracilariopsis lemaneiformis by Fredericq and Hommersand [41]. The cells of carposporangia show heterogenous mixture of polysaccharides, floridean starch grains and protein contents (present study). This work suggests that the size of carposporangia varies considerably among the different species studied. Large oval shaped carposporangia are found in case of Gracilariopsis megaspora. Bird and Oliveira [29] reported the larger size of carposporangia $(\leq 50 \mu \mathrm{m})$ in G. megaspora.

\subsection{Analysis of Agar}

The treatment of agar by alkali eliminates the primary sulphate ester at 6-C of the L-linked galactopyranose unit giving rise to 3,6-anhydrogalactose. Thus, the present work confirms that the strength of agar is much improved by pre alkaline treatment. The presence of sulphate content in the untreated samples reduced adversely the gel strength of the agar. Amongst the two methods (non-alkali treatment), the method used in Thailand shows better yield with low gel strength and viscosity, this confirms that the quality of agar and can be used as food grade agar. Hemmingson and Furneaux, [42] reported a method to maximize the gel strength of agar from $G$. chilensis, as a practical post harvest light deprivation regime which might 
be an environmentally friendly alternative to the chemical processing (Alkali treatment) for food grade agar. A number of studies have been made to improve the gel strength of agar. The gel strength of agar depends on the post-alkali treatment step, wherein the best result was obtained if the $\mathrm{pH}$ of the seaweed could be maintained in the range 7 - 8 [43]. This prevents degradation of the acid-sensitive galactan polymer backbone present in the cell wall, which contains the 3,6-anhydrogalactose moieties that are responsible for the high gel strength, presumably due to the build-up of local concentrations of acid during neutralization. The agar yield decreased as the concentration of $\mathrm{NaOH}$ increased in all the seaweed species studied. The decrease in yield of alkali-treated agar compared to that of non alkali method may be attributed to the possible degradation and losses of the polysaccharides in the alkaline liquor $[43,44]$. Poppymary Vimalabai et al., [45] studied the seasonal variation on the yield and physical properties of agar in G. crassa, $G$. corticata var. cylindrica and $G$. foliifera. They found a variation in gel strength from 19 to 105,46 to 120 and 29 to $140 \mathrm{~g} / \mathrm{cm}^{2}$ in G. crassa, G. corticata var. cylindrica and $G$. foliifera respectively. Agar yield varied strongly similar to other agarophytes. The high agar yield of $G$. verrucosa in the present study proves its increased market demand and global exploitation. This study also supports the report of Kakita et al. [2]. Some researcher studied that low water temperature may a requisite for high gel strength and low salinity for good agar [46-53]. Further, the present study suggests that the agar quality can be 8 enhanced more for the commercial exploitation using the protocol of [54]. In addition, the "sugar reactivity" of the agars of $G$. edulis and G. crassa has been reported [55]. These gel-forming properties of agar are widely used in pharmaceutical, cosmetics and food industry.

\section{Conclusion}

The species G. verrucosa, G. edulis and G. crassa occurring in Indian waters could be taken up as large scale cultivation for commercial exploitation and constant supply of raw materials to seaweed industries. Future studies on the seawater parameters may be helpful for developing an elite germplasm yielding higher yield as well as quality agar and providing other information on the peak period of harvest.

\section{Acknowledgements}

The authors duly acknowledge the Department of Science and Technology, Govt. of India, New Delhi for their financial support to carry out the study.

\section{REFERENCES}

[1] D. J. Mc Hugh, "Worldwide Distribution of Commercial
Sources of Seaweeds including Gelidium," Hydrobiologia, Vol. 221, 1991, pp. 19-21. http://dx.doi.org/10.1007/BF00028359

[2] H. Kakita, H. Kamishima, A. Chirapart and M. Ohno, "Marine Biopolymers from the Red Algae, Gracilaria spp.," Recent Advances in Marine Biotechnology, Vol. 9, Science Publishers, 2003, pp. 79-109.

[3] S. Arasaki and T. Arasaki, "Vegetables from the sea," Japan Publishing Inc., Tokyo, 1983, 196 p.

[4] G. R. South, "Gracilaria maramae sp. nov. (Gracilariaceae, Gracilariales, Rhodophyta), an Economically Important Species from the Fiji Islands, South Pacific," In: J. A. Abbott, Ed., Taxonomy of Economic Seaweeds, Vol. California Sea Grant Program, 1995, pp. 177-184.

[5] M. Ohno, R. Terada and H. Yamamoto, "The species of Gracilaria from Vietnam," In: I. A. Abbott, Ed., Taxonomy of Economic Seaweeds, Vol. VII I. California Sea Grant College System, 1999, pp. 99-111.

[6] T. Ajisaka and Y. M. Chiang, "Recent status of Gracilaria, cultivation in Taiwan," Hydrobiologia, Vol. 260/261, 1993, pp. 335-338.

http://dx.doi.org/10.1007/BF00049037

[7] R. A. Fralick, J. E. Hugenin and B. E. Lapointe, "The Growth of Commercially Useful Seaweeds in a Nutrient Multipurpose Aquaculture System," International Seaweed Symposium, The Marine Science Laboratories, Gwynned, 1981, pp. 692-698.

[8] J. H. Ryther, J. A. DeBoer and B. E. Lapointe, "Cultivation of Seaweeds for Hydrocolloids, Waste Treatment and Biomass for Energy Conservation," International Seaweed Symposium, Science Press, Princeton, 1979, Vol. 9, pp. 1-6.

[9] D. Hanisak and J. H. Ryther, "The Experimental Cultivation of the Red Seaweed Gracilaria tikvahiae as an "Energy Crop": An Overview," Nova Hedwigia, Vol. 83, 1986, pp. 212-217.

[10] A. Flowers and K. T. Bird, "Methane Production from Seaweeds," In: I. Akatsuka, Ed., Introduction to Applied Phycology, Academic Publishing, Hague, 1990, pp. 575587.

[11] D. B. Sahoo, "Farming the Ocean: Seaweeds Cultivation and Utilization," Aravali Books International, New Delhi, 2000, p. 283.

[12] M. Ganesan, N. Sahu and K. Eswaran, "Raft Culture of Gracilaria edulis in Open Sea along the South-Eastern Coast of India," Aquaculture, Vol. 321, 2011, pp. 145151. http://dx.doi.org/10.1016/j.aquaculture.2011.08.040

[13] D. Sahoo, N. Sahu and D. B. Sahoo, "A Critical Survey of Marine Algal Flora of Chilika Lake, India," Algae, Vol. 18, No. 1, 2003, pp. 1-12.

http://dx.doi.org/10.4490/ALGAE.2003.18.1.001

[14] N. Sahu, "Studies on Gracilarioids from Chilika LakeStructure, Development and Agar Quality," Ph.D. Thesis, University of Delhi, 2004, p. 163.

[15] D. B. Sahoo, "Nivedita and Debasish Seaweeds of Indian Coast," APH Publishing Corporation, New Delhi, 2001, p. 283.

[16] D. B. Sahoo, N. Sahu, D. Sahoo and P. Baweja, "Marine 
Algae Cultivation Option for Sustainable Management of Chilika Lake," In: T. V. Ramachandra, N. Ahalya and C. R. Murthy, Eds., Aquatic Ecosystems: Conservation, Restoration and Management Capital Publishing House, New Delhi, 2005, pp. 278-283.

[17] S. Istini, M. Ohno and K. Kusunose, "Method of Analysis for Agar, Carrageenan and Alginate in Seaweed," Bulletin of Marine Science Fishery, Kochi University, No. 14, 1994, pp. 49-55.

[18] B. A. Kalkman, "Extraction of Agar from Gracilaria edulis as a Village Level Technology-Preliminary Results," Report of the Seminar on Gracilaria Production and Utilization in Thereby of Bengal, Songkhla, 1989, pp. 54-57.

[19] S. Fredericq and M. H. Hommersand, "Comparative Morphology and Taxonomic Status of Gracilariopsis (Gracilariales, Rhodophyta)," Journal of Phycology, Vol. 25, 1989, pp. 228-241.

http://dx.doi.org/10.1111/j.1529-8817.1989.tb00117.x

[20] M. Umamaheswara Rao, "On the Gracilariceae on the Seas around India," Journal of the Marine Biological Association of India, Vol. 14, No. 2, 1972, pp. 671-696.

[21] G. L. Cote and M. D. Hanisak, "Production and Properties of Native Agars from Gracilaria tikvahiae and Other Red Algae," Botanica Marina, Vol. 29, 1986, pp. 359366. http://dx.doi.org/10.1515/botm.1986.29.4.359

[22] H. Ohmi, "The Species of Gracilaria and Gracilariopsis from Japan and Adjacent Waters," Bulletin of the Faculty of Fisheries, Kokkaido University, Vol. 6, No. 1, 1958, pp. 1-66.

[23] A. T. Critchley, "Gracilaria (Rhodophyta, Gracilariales): An Economically Important Agarophyte," Seaweed Cultivation and Marine Ranching. Kanagawa International Fisheries Training Center, JICA, 1993, pp. 89-112.

[24] M. Steentoft, L. M. Irivine and W. F. Farnham, "Two Terete Species of Gracilariopsis (Graciariales, Rhodophyta) in Britain," Phycologia, Vol. 34, 1995, pp. 113-127. http://dx.doi.org/10.2216/i0031-8884-34-2-113.1

[25] R. K. Greville, “Algae Britannicae," MacLachlan \& Stewart, Edinburgh, 1830, p. 218.

[26] E. Y. Dawson, "Studies of Northeast Pacific Gracilariaceae," Allan Hancock Fdn. Publ. Occ. Pap, Vol. 7, 1949, pp. 1-105.

[27] A. F. Withell, A. J. K. Millar and G. T. Kraft, "Taxonomic Studies of the Genus Gracilaria (Gracilariales, Rhodophyta) from Australia," Australian Systematic Botany, Vol. 7, 1994, pp. 281-352. http://dx.doi.org/10.1071/SB9940281

[28] T. V. Desikachary, V. Krishamurthy and M. S. Balakrishnan, "Rhodophyta. Madras Sc. Foundation," Vol. II-PartIIB, Chennai, 1998, p. 359.

[29] C. J. Bird and E. C. Oliveira, "Gracilaria lenuiforns sp. nov. (Gigartinales, 1Rhodophyta), a Species from the Tropical Western Atlantic with Superficial Spermatangia," Phycologia, Vol. 25, 1986, pp. 313-320. http://dx.doi.org/10.2216/i0031-8884-25-3-313.1

[30] L. Talarico, D. Domevscek and E. Murano, "Structure and Composition of the Cell Wall of Gracilaria verrucosa (Huds.) Papenfuss (Gigartinales-Rhodophyta) after Steam
Explosion," Giornale Botanico Italiano, Vol. 124, No. 5, 1990, pp. 700-701.

[31] M. Kumar, "Studies on Life Cycle of the Red Alga Gracilaria corticata," J. A. Agardh, Ph.D. Thesis, University of Delhi, Delhi, 1996, p. 107.

[32] B. Kloreg and R. S. Quatrano, "Structure of the Cell Walls of Marine Algae and Ecophysiological Functions of the Matrix Polysaccharides," Oceanography and Marine Biology-An Annual Review, Vol. 26, 1988, pp. 259315.

[33] L. G. Sjostedt, "Floridean studies. Aota Univ. Lund, N.F. Avd. 2," Vol. 22, No. 4, 1926, pp. 1-95.

[34] V. Krishnamurthy and N. R. Rajendran, "Gonimonema, a Structural Feature of Gracilaria," Seaweed Research Utilization, Vol. 10, 1987, pp. 9-15.

[35] H. Yamamoto, "Systematic and Anatomical Study of the Genus Gracilaria in Japan," Memoirs of the Faculty of Fisheries, Hokkaido University, Hokkaido, 1978, Vol. 25, pp. 97-152.

[36] V. Krishnamurthy and N. R. Rajendran, "On Four Species of Gracilaria from Tamil Nadu," Seaweed Research and Utilisation, Vol. 9, No. 1-2, 1986, pp. 97-109.

[37] G. M. Gargiulo, F. De Masi and G. Tripodi, "Morphology, Reproduction and Taxonomy of the Mediterranean Species of Gracilaria (Gracilariales, Rhodophyta)," Phycologia, Vol. 31, No. 1, 1992, pp. 53-80. http://dx.doi.org/10.2216/i0031-8884-31-1-53.1

[38] C. F. Chang and X. Bangmei, "Some Problems in the Taxonomy of Chinese Species of Gracilaria (Rhodophyta)," Hydrobiologia, Vol. 116-117, No. 1, 1984, pp. 59-62. http://dx.doi.org/10.1007/BF00027640

[39] J. Zhang and B. Xia, "On Two Gracilaria (Gigartinales, Rhodophyta) from South China," In: I. A. Abbott, Ed., Taxonomy of Economic with Reference to Some Pacific and Caribbean Species, Vol. II. California Sea Grant College, University of Caliofornia, La Jolla, 1998, fig. 1-17, pp. 131-136.

[40] I. A. Abbott, "New Species of Gracilaria Grev. (Gracilariaceae, Rhodophyta) from California and Hawaii," In: I. A. Abbott and J. N. Norris, Eds., Taxonomy of Economic Seaweeds with Reference to Some Pacific and Caribbean Species. California Sea Grant College Program, University of California, La Jolla, 1985, pp. 115-121.

[41] S. Fredericq and M. H. Hommersand, "Proposal of the Gracilariales Ord. Nov. (Rhodophyta) Based on the Analysis of the Reproductive Development of Gracilaria verrucosa," Journal of Phycology, 1989, Vol. 25, No. 2, pp. 213-227.

http://dx.doi.org/10.1111/j.1529-8817.1989.tb00116.x

[42] J. A. Hemmingson and R. H. Furneaux, "Variation of Native Agar Gel Strength in Light Deprived Gracilaria chilensis Bird, McLachlan et Oliveira," Botanica Marina, Vol. 46, No. 3, 2003, pp. 307-314.

http://dx.doi.org/10.1515/BOT.2003.027

[43] A. K. Siddhanta, R. Meena, K. Prasad, B. K. Ramavat, P. K. Ghosh, K. Eswaran, S. Thiruppathi and V. A. Mantri, "A Cost-Effective Process for Preparing Agarose from Gracilaria Spp.," US Patent No. 2005/ 0267296 A1, 1 
December 2005, PCT: W0 2005/118830.

[44] Y. Freile-Pelegrın and D. Robledo, "Influence of Alkali Treatment on Agar from Gracilaria cornea from Yucatan, Mexico," Journal of Applied Phycology, Vol. 9, No. 6, 1997, pp. 533-539.

[45] C. Poppy Mary Vimalabai, S. Sudhadevarani and R. N. Devi, "Carbohydrate and Vitamin-C Contents of Some Macroalgae of Tuticorin, Southeast Coast of India," Seaweed Research and Utilisation, Vol. 25, No. 1-2, 2003, pp. 47-53.

[46] C. Sasikumar, V. N. Rao and R. Rengaswamy, "The Effect of Environmental Factors on the Quanlitative and Quantitative Characteristics of Agar from the Marine Red Alga Gracilaria verrucosa (Gracilariales, Rhodophyta)," Indian Journal of Marine Sciences, Vol. 28, No., 1999, pp. 270-273.

[47] P. C. Thomas, K. R. Rao and K. Subbaramaiah, "Periodicity in Growth and Production of Agar of Gelidiella acerosa (Forsskal) Feld Et Hamel," Indian Journal of Marine Sciences, Vol. 4, No., 1975, pp. 210-212.

[48] R. M. Oza, "Studies on Indian Gracilaria IV. Seasonal Variation in Agar and Gel Strength of Gracilaria corticata, J. Ag. Occurring on the Coast of Veraval," Botanica Marina, Vol. 21, No. 3, 1978, pp. 165-167. http://dx.doi.org/10.1515/botm.1978.21.3.165

[49] Y. Freile-Pelegrin, D. R. Robledo and G. G. Reina, "Seasonal agar yield and quality in Gelidium canariensis (Grunow) Seoane Camba (Gelidiales, Rhodophyta) from Gran Canaria, Spain," Journal of Applied Phycology, Vol. 7, No. 2, 1995, pp.141-144.

[50] E. C. Oliveira, R. M. Saito, S. Neto and G. M. C. Garofalo, Temporal and Spatial Variation in Agar from a Popu- lation of Pterocladia capillacea (Gelidiales, Rhodophyta) from Brazil," Hydrobiologia, Vol. 326-327, No. 1, 1996, pp. 501-504. http://dx.doi.org/10.1007/BF00047852

[51] S. M. Phang, S. Shaharuddin, H. Noraishah and A. Sasekumar, "Studies on Gracialria changii (Gracilariales, Rhodophyta) from Malaysian Mangroves," Hydrobiologia, Vol. 326-327, No. 1, 1996, pp. 347-352. http://dx.doi.org/10.1007/BF00047829

[52] R. D. Villanueva, N. E. Montano, J. B. Romero, A. K. A. Aliganga and E. P. Enriquez, "Seasonal Variations in the Yield, Gelling Properties and Chemical Composition of Agars from Gracilaria eucheumatoides and Gelidella acerosa (Rhodophyta) from the Philippines," Botanica Marina, Vol. 42, No. 2, 1999, pp. 175-182. http://dx.doi.org/10.1515/BOT.1999.020

[53] M. Yenigul, "Seasonal Changes in the Chemical, and Gelling Characteristics of Agar from Gracilaria verrucosa Collected in Turkey," Hydrobiologia, Vol. 260-261, No. 1, 1993, pp. 627-631.

http://dx.doi.org/10.1007/BF00049081

[54] R. Meena, K. Prasad, M. Ganesan and A. K. Siddhanta, "Superior Quality Agar from Gracilaria Species (Gracilariales, Rhodophyta) Collected from the Gulf of Mannar, India," Journal of Applied Phycology, Vol. 20, No. 4, 2008, pp. 397-402. http://dx.doi.org/10.1007/s10811-007-9272-6

[55] R. Meena, K. Prasad and A. K. Siddhanta, "Studies on 'Sugar Reactivity' of Agars Extracted from Some Indian Agarophytes," Food Hydrocolliods, Vol. 20, No. 8, 2006, pp. 1206-1215. http://dx.doi.org/10.1016/j.foodhyd.2006.01.005 